\title{
ISLAMIC JURISDICTION: SHARIE'A COURTS AND THE FUTURE OF PUBLIC POLICY
} JURISDIÇÃO ISLÂMICA: OS TRIBUNAIS DE SHARIA E O FUTURO DA POLÍTICA
PÚBLICA

\section{Pohamed Abdelhamied Ahmed Abdou Arafa} Possui graduação em Bachelor of Laws, LL.B. pela Alexandria University(2006) e doutorado em Juridical Science pela Indiana University Robert H. McKinney School of Law(2013). Atualmente é professor adjunto da Indiana University, Professor visitante de matérias no Direito da The British University School of Law, Professor assistente da Alexandria University e Professor visitante de matérias no direito da Arab Academy for Science, Technology \& Maritime Transport.

\section{Resumo}

O direito egípcio preservou o sistema islâmico de direito interreligioso, no qual as sociedades muçulmana, cristã e judaica são governadas cada qual por seus próprios tribunais e leis. Porém, no decorrer do século $X X$, tal separação foi abolida e a aplicação das leis não-muçulmanas foi limitada a questões de casamento e divórcio, e, ainda, somente nos casos em que os cônjuges nãomuçulmanos compartilhassem o rito da mesma religião. Em todos os outros, aplica-se o direito islâmico (Sharia). Além disso, as leis nãomuçulmanas podem não ser aplicadas se violarem a "política pública" egípcia, conceito europeu que se refere aos fundamentos de uma ordem jurídica nacional. A política pública egípcia pode ser definida por aqueles princípios que são indispensáveis ao direito islâmico. Este artigo analisa, com base na jurisprudência e na doutrina jurídica egípcia, o status do egípcio não muçulmano na moderna Lei do Status Pessoal. O conceito de política pública desempenha um papel fundamental na compreensão da mecânica do direito inter-religioso no Egito. As políticas públicas servem como um barômetro jurídico da coexistência de comunidades muçulmanas e não muçulmanas no Egito.

Palavras-chave: Direito Islâmico, Sistema jurídico, Egito, Política Pública, Direito Penal, Direito de Família.

\begin{abstract}
Egyptian law has preserved the Islamic system of interreligious law in which the Muslim, Christian and Jewish societies are governed by their own courts and their own laws. In the course of the twentieth century, but, these separate courts were abolished and the application of non-Muslim laws was limited to matters of marriage and
\end{abstract}


divorce, and then only if the non-Muslim spouses share the rite and sect of the same religion. In all other cases Islamic law (Sharie'a) applies. In addition, non-Muslim laws may not be applied if they infringe Egyptian 'public policy', a European concept which refers to the fundamentals of a national legal order. Egyptian public policy can be defined as those principles which are indispensable in Islamic law. This paper, analyze the status of the non-Muslim Egyptian in modern personal status law, based on Egyptian case law and legal literature. The concept of public policy plays a key role in understanding the mechanics of interreligious law in Egypt. It argues that public policy serves as a legal barometer of the coexistence between Muslim and non-Muslim communities in Egypt.

Keywords: Islamic law, Sharie'a, Legal System, Egypt, Public Policy, Criminal Law, Family Law.

\section{I - Introduction and Overview}

Recently the issue of the Sharie'a courts has been drawing the attention of the Western media, especially in Europe, Canada, and the United States. Legal scholars and legal activists are quite reluctant to contribute to the discourse held mostly by reporters, religious figures and politicians. This could be why the matter is covered cursorily resting upon emotional, prejudiced and politically inspired debates and valuations. Moreover, the Sharie'a court's jurisdiction is not always obviously specified and fundamentally various issues of these courts get mixed and sometimes led to the conflict of laws (choice of law) questions.

In Contemporary Egypt, the Muslims, Christians and Jews are governed by the personal status laws of their societies. This implies that the personal status (family law) of Egypt's legal subjects is based on their belonging to a religious community. In this respect, a person without religion is a legal non-entity. The Egyptian legal literature refers to the coexistence of religious rules as the ta'addud al-shara' (plurality of "religious" laws), instead using the term 'interreligious law,' which is common in most European literature. In this paper, will examine the relations and tensions between these legal spheres in Egypt. What if the laws of one religious community contradict (challenge) or violate the values of another community? Is there a hierarchy among these laws? Which law applies in case of conversion to the religion of another community or in case of intermarriage between members of different communities? Also, it will focus on conflict of laws, that is the legal procedure used to determine which law is applicable in a case in which more than one law applies to a situation (e.g., the marriage between a Catholic and a Copt or between a Copt and a Muslim).

Readers - who are not lawyers - should note that the term conflict of laws is typically booked for the field of private international law, which deals with conflicts between laws of different countries. This article, however, discusses the issue of the conflicts between laws of different religious communities within a single country (the procedure to solve these conflicts 
as interreligious conflicts law). Egypt's interreligious conflicts law is codified in Law 462 of 1955, which allows the application of non-Muslim family laws, albeit under certain conditions, and only within the limits of al-nizam al-'amm (public policy). The term public policy (also known as ordre public) is of European origin and was introduced into Egyptian legal doctrine at the end of the nineteenth and the beginning of the twentieth century. The terms public policy and ordre public can be confusing, since they recall state policy or the law and order's maintenance. This is not the case in conflicts law, where public policy is a technical term denoting the principles which are considered of crucial significance to a national legal order. To accommodate the changes in social, economic, societal, and moral values, the interpretation of public policy is usually left to the courts rather than defined by law. The understanding of public policy may differ from one country to the next, and these differences are an important indicator of the principles held dear by a society, as public policy plays a crucial role in Egyptian interreligious law. This interpretation is coming from two major sources: the Egyptian legal literature and the rulings of the Egyptian Court of Cassation - the highest court in the land - in civil cases.

\section{Justice under Sharie‘a Law: Muslim Ummah's (Nation) Modern Practices, Status Quo}

Justice and law have always taken a momentous position in the Islamic fiqh (jurisprudence), as a science of rules governing the express behavior of human beings. ${ }^{1}$ In this respect, a famous statement written by 'Umar ibn alKhattab - the second Caliph (companion) of Prophet Mohammad - about the Sharie'a judiciary describing it as a benchmark as it covers all the main legal issues of the Sharie' $a .^{2}$ It should be noted that in the Islamic legal theory, the characteristic features of Islamic law concurrently manifest themselves both in the organization and functioning of the Sharie'a courts. ${ }^{3}$ It should be mentioned that the Sharie'a courts - as state institutions - play a critical role in the enforcement of Islamic law and according to figh, the major designation of the power is the application of Sharie' $a$ and this task is completed in the activity of judicial bodies. ${ }^{4}$ In terms of the concept of the separation of powers, modern Islamic legal thought addresses the leading role of the judicial power not the legislative one and the practical effect of the Sharie'a rules is impossible without the Islamic judicial bodies

\footnotetext{
1 See IBN AL-KAYYIM AL-GaWZIYYA, Admonition for Those Who Sing on Behalf of the Master of the Worlds, Ch. 1, at 86-383 \& Ch. 2, at 3-182 (Beirut in Arabic).

${ }^{2}$ Natasha Bakht, Family Arbitration Using Sharia Law: Examining Ontario's Arbitration Act and its Impact on Women, 1 MUSLIM WORLD J. HUMAN RIGHTS 1 (2004), at 7.

${ }^{3}$ See AL-MARSOUM BI-QANUN: RAQm 78 II-SANNA 1931 Al-MUSHTAMII 'A/A LAI HA TARTI B AL-MAHAKIM ALSHARFA. (emphasis added, as most of its rules were abolished by Law 462 of 1955).

${ }^{4}$ See The Explanatory Memorandum to Law 462 of 1955, and the Court of Cassation (cf. Nr. 29, Year 34, March 30,

1966; Nr. 8, Year 36, February 14, 1968; Nos.16 and 26, Year 48, January 17, 1979).
} 
implementing the principal function of the Islamic state. ${ }^{5}$

Historically in most Arab and Muslim countries, Sharie'a courts precisely were the core of the judicial system and ensured Sharie'a's implementation. The reform started changing in the second half of the $19^{\text {th }}$ century when a deep political and administrative transformations in the Ottoman Empire and Egypt involved a shift of positions, as in more developed Muslim countries, Islamic law gave dominant place in the legal system to the civil European statutes. ${ }^{6}$ In most countries these court's jurisdiction was limited to the consideration of the family law (personal status) of Muslims. ${ }^{7}$ The reforms of the $19^{\text {th }}$ century determine the specifics of the Islamic judicial bodies which function in the Muslim world today and that depends on the position Islamic law occupies in the legal development in many Middle Eastern and Muslim countries. $^{8}$

Currently, the organization of Sharie'a courts and the procedural rules implemented by them include traditional Islamic rules and institutions with forms compatible with the modern civil European law. ${ }^{9}$ Generally, classical Sharie'a justice was based upon the sitting of a single qadi (judge), while nowadays a panel hearing is the rule, as in the Middle Ages, Sharie'a courts operated on one instance (level) and court verdicts delivered by them were considered irrevocable. ${ }^{10}$ In all Muslim countries - at the current moment - with such courts there is a multi-level system of Sharie'a judicial bodies which entails the option - and in certain cases even necessity - of an appeal of a decision taken by the court in the first instance. ${ }^{11}$ Thus, Sharie' a justice comprises the regular application of the Islamic values by the court and specific procedural instructions (as testimonial evidence for proving legal facts) expounded by Islamic

\footnotetext{
5 See generally Leonid R. Sykiainen, Islamic Law: Interaction between Legal and Religious Sides, 1 ANN'L OF LiberTARIAN LEGAL THEORY (2007). See also Shariah in American Courts: The Expanding Incursion of Islamic Law in the U.S. Legal System. CENTER FOR SECURITY POLICY PRESS (Washington D.C. 2014).

${ }^{6}$ See generally MuHAmmad BAQIR Al-SAdR; HAmid Alagr, \& ARIF Abdul Hussain (translator), Principles of Islamic Jurisprudence: According to Shi'i Law (2005). In this regard, it should be noted that the Sharie'a courts were expressively altered as a result of those changes.

7 See generally Wael B. Hallaq, The Formation of Islamic Law (Ashgate/Variorum 2004) (discussing the emergence and evolution of law during the first three and a half centuries of Islam and reflect the different and, at times, widely divergent scholarly approaches to this subject matter [Sharie'a courts]).

${ }^{8}$ However, the modifications these bodies meaningfully differ from traditional Sharie'a courts working in medieval Muslim countries and, furthermore, from the ideal model of the Sharie'a justice explained by classical figh.

9 See generally Wael B. Hallaq, A History of Islamic Legal Theories (Ashgate/Variorum 1997) (elaborating the history of Islamic legal theory from its early beginnings until the modern period, especially the early formation of this theory, analyzing its central themes and examining the developments which gave rise to a variety of doctrines along with a discussion of modern thinking about the theoretical foundations and methodology of Islamic law).

$10 \mathrm{ld}$. Given the modern practice of some Muslim countries the Sharie'a system of justice should not be understood as a certain form of court but a model which is different due to specific Sharie'a-related features.

${ }^{11} \mathrm{ld}$. It is conceivable to recognize some modern Sharie'a courts - or to be more precise - some forms of the imposition of the Sharie'a model of the judiciary or elements of it in the contemporary judicial and legal system of Arab and Muslim nations.
} 
legal doctrine. ${ }^{12}$

In some Muslim countries, all regular courts are called Sharie'a courts, however, they are not always Sharie' a courts in the precise sense. ${ }^{13}$ The uniqueness of the judicial system of Pakistan - in that regard for example - is that it comprises the Federal Sharie'a court established in 1980, as a body of constitutional control since it is authorized to check the compliance of all laws and regulations adopted in the country to Sharie'a standards. ${ }^{14}$ In some modern Muslim countries, as Jordan and Lebanon, there are independent Sharie'a courts for the resolution of disputes concerning family law issues linked with personal status of Muslims on the basis of Islamic law, operating in the form the modern figh (Islamic legal doctrine). ${ }^{15}$ In Egypt, such courts are called family courts but in fact they are also Sharie'a judicial bodies. ${ }^{16}$ The Sharie'a justice institutions regarding both procedure and substantive rules explains why other courts of general jurisdiction in Muslim countries cannot be called Sharie' $a .{ }^{17}$ In this respect, it should be noted that Sharie'a justice philosophies work partially in those non-Muslim countries of Asia and Africa where Muslims are the minority but are customarily entitled to govern relations of their personal status in accordance with the Sharie'a principles, as in India, Israel or South Africa with Sharie'a courts applying Islamic law to issues of marital relations. ${ }^{18}$

\footnotetext{
${ }^{12}$ Hallaq, supra note 7 . Some of the courts have administrative or structural principles are distinctive in their features, mainly with respect to the requirements imposed on the judges. Records of the operations of sharia courts during the British occupation of Egypt are quite limited. This gap in the literature is due in part to the fact that the jurisdiction of the qadis had been shrinking since the reign of the Mamluk Sultanates in the $13^{\text {th }}$ century. As reformers and many scholars have argued, the marginalization of the sharia courts was a byproduct, rather than primary objective of the legal reforms. However, whether intentional or not, the result was the same: by the late $18^{\text {th }}$ century, the jurisdiction of sharia courts was largely restricted to personal status matters. Though it is easy to interpret these reforms as the infiltration of imperial powers into Muslim judiciaries, the history tells a different story. The legal reform policies were primarily the products of Egyptian and Ottoman administrations which sought to take advantage of foreign investment and consolidate power. When the British officially began occupying the country in 1882, they adopted - rather than created - the scheme of restricting the power of the qadis (judges).

${ }^{13}$ Mohamed 'Arafa, Islamic Criminal Law: The Divine Criminal Justice System between Lacuna and Possible Routes, 2 FoRENSIC \& CRIME ST. J. 102 (2018). For instance, in Saudi Arabia, courts of general jurisdiction are not just called Sharie'a courts but they really are. According to the nizam (order) regarding the judiciary, all courts are obliged to implement, Sharie'a - according to their Hanbali or Wahabi interpretation - and only then the state normative acts which do not contradict it. The current procedural legislation for administrative courts implements numerous Sharie'a rules, and recruits only judges who have certificates or diplomas of Sharie'a educational credentials.

${ }^{14}$ Nicholas Heer and Farhat Jacob Ziadeh, ISLAMIC LAW-JURISPRUDENCE (Washington Univ. Press 1990). The appellate court for judgements represents the courts of general jurisdiction passed in accordance with the law which states Sharie'a punishment for certain criminal activities.

${ }^{15}$ Wael B. Hallaq, Law and Legal Theory in Classical and Medieval Islam (Variorum 1994) (discussing the law and legal theory in classical and medieval Islam; regarding the non-analogical arguments in Sunni juridical Qiyas; logic and formal arguments in Sunni jurisprudence; inductive corroboration; and al-Shafi $i$ and his influence on Islamic jurisprudence).

16 It should be noted that the judicial systems of countries as Libya, United Arab Emirates, and Kuwait do not include Sharie'a courts and generally are guided by European civil traditions. However, regular courts use principles of Islamic law for example, to resolve disputes on family and inheritance issues.

17 Hallaq, supra note 15. They not only underscore the Islamic law rules occasionally, for instance, litigation of Islamic business organizations negotiating deals using the Sharie'a conditions but also within the framework of general procedural norms not using the Islamic or divine criteria.

18 ld. The Islamic personal status law in Egypt is codified only in matters of succession, guardianship,
} 


\section{Sharie‘a Courts in Egypt: Still There in Reality or Abolished?}

\section{A. Literature Review: Early Sharie‘a Courts}

Islamic law began to take shape as Prophet Mohammad settled into Medina in response to the established codes of the Jewish and Christian populations living in the city. These early laws were based heavily on Arab tribal values, namely the Sunan (norms). Similar to modern hadiths, the Sunan presented exemplary conduct for Muslims to follow and laid the early foundations for Sharie'a. This was a revolutionary development. Thus, there was no religious law based on existing tribal laws. However, by vivifying Islamic values, Mohammad was creating a religion-based normative legal structure through the Sunan. ${ }^{19}$ On principle, Islamic law was never enforced over conquered communities. This policy of doctrinal legal pluralism would become a signature of the Islamic empires, and ultimately allow European powers to infringe upon their sovereignty. ${ }^{20}$ In the $9^{\text {th }}$ century, as the garrison towns grew into metropolitan cities and conquered people became more religious, qadis (judges) were required to abandon their roles as tax collectors and storytellers for full-time litigation duties. ${ }^{21}$ Accordingly, qadis were expected to hold extensive religious knowledge in order to adjudicate cases based on the Qur anic texts and hadiths. As representatives for the highest courts in the land, qadis of this era saw all cases regarding penal, civil, criminal, and personal statutes. Only the governor-administrated mazalim (complaints) tribunals held overlapping jurisdictions with the Sharie'a courts. ${ }^{22}$ But even then, the qadis, with legal supremacy, could exercise veto power over any decisions made by the mazalim magistrate. ${ }^{23}$

The Ottoman Empire's judicial system, much like previous Islamic empires, was defined by legal pluralism. The qadis presided over but one of a handful of executive and

\footnotetext{
legal capacity, family relations, and some aspects of marriage and divorce. The non-codified rules of Islamic personal status law are based on the jurisprudence of the Hanafi school.

${ }^{19}$ Soon after the Prophet's death, the position of the qadi (judge) was established. In the early days of Islamic expansion, these judges had wide-ranging duties like storytelling and policing in addition to providing legal oversight. These broad duties were the product of the narrow territorial jurisdiction of the time. Qadis at the time only presided over the affairs of Muslim Arab territories and the garrison towns of the conquering armies.

${ }^{20}$ See generally James E. Baldwin, ISLAMIC LAW AND EMPIRE IN OTTOMAN CAIRO (2017).

21 ld.

22 James E. Baldwin, Cairo's Legal System: Institutions and Actors in ISLAMIC LAW AND EMPIRE IN OTTOMAN CAIRO (2017), at 33-54.

${ }^{23} \mathrm{Id}$. From the $9^{\text {th }}$ to the $13^{\text {th }}$ century, Sharie'a courts reached their zenith of power. Their jurisdiction included a wide range of issues and there were few challenges to their authority. The rise of the Mamluk Sultanate marked a turning point in their judicial standing as legal reforms allowed the administration to assume portions of the qadis' original jurisdiction. This marginalization of traditional duties, in addition to the strengthening of parallel judicial institutions set the stage for the Ottoman sidelining and co-option of the Sharie'a courts.
} 
religious courts. The jurisdictions of various courts and tribunals often overlapped, creating a confusing legal environment. It is difficult to discern the rationale behind the creation of such convoluted jurisdictions. ${ }^{24}$ After defeating the Mamluk Sultanate of Egypt, the Ottomans sought to consolidate their power over the preexisting religious institutions. The mixed-madhab nature of the Cairo courts presented a challenge to the Hanafi ilimye, the Ottoman institution tasked with enforcing Sharie'a. The Mamluk policy of judicial inclusion had created a setting where qadis from each madhab (school of thought) held significant power within the court system though Shafi's were - still given deference. ${ }^{25}$ The traditional duties of the qadis like marketplace regulation, and maintaining public morality were transferred to professional police forces or bureaucrats leaving the Sharie'a courts to deal only with personal matters like property and family disputes. ${ }^{26}$ Even with these enduring responsibilities, the Porte had methods for restricting the Sharie'a courts' jurisdiction. ${ }^{27}$

Implementation of these legal reforms were incredibly slow due to the weak nature of the Ottoman state. Beginning with the first Capitulation to the French in 1535, Constantinople set the trend for sacrificing sovereignty for the sake of foreign investment. Egypt, because of the large presence of powerful European populations, was the scene of the most far-reaching concessions. Accordingly, the Capitulations guaranteed foreigners, (a) freedom of residence and trade; (b) freedom of religion; (c) immunity from all direct tax; (d) consular jurisdiction over crimes by their nationals, and consular jurisdiction over civil cases where their national was a defendant, and (e) freedom from domiciliary search unless the consul was present. ${ }^{28}$ These concessions had devastating effects on the Egyptian government's ability to enforce the law. While it was within Muslim tradition to allow religious minorities to handle matters of personal status in their respective courts, the total surrender of civil and penal infractions to foreign tribunals was a completely different matter. ${ }^{29}$ Thus, the Tanzimat during the $19^{\text {th }}$ century only

${ }^{24} \mathrm{Id}$. Some have argued that the legal pluralism was designed to divide and weaken existing judicial structures, while other scholars have noted that legal pluralism has been a major component of Islamic empires since their advent. Both of these arguments provide a valuable framework for interpreting the legal reform policies leading up to the British occupation in 1882.

${ }^{25}$ Baldwin, supra note 22. Thus, the Ottoman attempt to Hanifize the courts was met with fierce opposition from the well-established non-Hanifi qadis. But the existing legal pluralism allowed the Porte's administrators to circumvent the Sharie'a courts by reallocating their jurisdiction to judiciaries more aligned with the Ottoman vision.

${ }_{26}$ The Diwan al'Ali - much like the mazalim under the Mamluk Sultanate - was established by executive authorities to deal with matters like petty theft which would normally be adjudicated by qadis. The final limitation to the qadis' ability to act independently during the early period came via the Ottoman inclination towards mediation over adjudication. This strong preference for mediation essentially stripped the qadis of their discretion in judging cases. Under the directive of the Porte, Sharie'a courts were expected to encourage the litigants to resolve their disputes independently, with qadis intervening only as a last resort.

${ }_{27}$ Baldwin, supra note 22, at 50 .

${ }^{28}$ See generally Reem A. Meshal, Sharia and the Making of the Modern Egyptian: Islamic Law and Custom in the Courts of Ottoman Cairo (2014).

${ }^{29} \mathrm{ld}$. The Ottomans themselves recognized the dangers of such concessions and refused to exempt foreigners in Turkey from taxes or search and seizure. With foreign consuls handling cases involving 
accelerated the reduction of Sharie'a jurisdiction. This era of modernization saw the adoption of more European-based codes and the rapid absorption of traditional Sharie'a court duties into the state bureaucracy. Hence, the new laws were designed to act in accordance to Sharie' $a$, nullifying the qadis' claims that the reforms were un-Islamic. ${ }^{30}$

Thus, the Mixed Courts, inaugurated in 1875, allowed the Egyptian government to once again exercise some autonomy over its judiciary, as this development further marginalized the power of the qadis. Though Article 11 of the Mixed Civil Code of Egypt officially integrated Sharie' a into the mixed judiciary normative process, qadis were rarely appointed to the mixed bar by the Khedive (leader). ${ }^{31}$ Sharie'a courts, after three centuries of marginalization were of negligible importance to the British during the occupation. The Sharie'a per se was still an important source of judicial legitimacy, but the state had integrated Islamic principles into the legal doctrine, making the qadis themselves largely irrelevant. ${ }^{32}$ Thus, from 1883 until their merger with the National Courts - under Egypt's former President Nasser - the operations of Sharie' a courts were officially limited to cases regarding personal status and family issues. ${ }^{33}$

The elimination of the Shari (religious) and communal courts in Egypt marks a vital point in the religious and political development of Egypt and possibly of other Arab countries. This conclusive step which has stimulated heated discourse in Egypt and other Muslim countries has not received the attention it deserves on the part of Islamists in the Middle East. ${ }^{34}$ It is important to delve into the immediate aspects of the law that abolished these courts and its substance, along with the reasons for its promulgation (significance), and its reflective actions to it in Egypt and other Arab countries. In 1955, a law has been enacted declares the abolition of the Shar $i$ and the communal courts. ${ }^{35}$ Further, the law regulates the way of moving lawsuits in numerous levels of Shar i and communal courts to the respective levels of domestic

non-Egyptians, Coptic and Jewish courts handing the cases of non-Muslims, and various Ottoman courts presiding over cases involving Egyptian Muslims, the jurisdiction of independent Sharie'a courts was very narrow going into the $19^{\text {th }}$ century.

30 These efforts to attract foreign investment were further advanced during the reign of Khedive Ismail, though he took a more measured approach. Throughout the 1860 s and 70 s, the Khedive negotiated the foundations for Mixed Courts which would hold jurisdiction over cases involving foreigners and Egyptians.

${ }^{31}$ After establishing the Mixed Courts, Ismail's successor began to consolidate the many components judicial apparatus into one secular National Court, which became operational in 1883. Combined, these new courts held jurisdiction over civil cases involving foreigners and Egyptians and penal cases involving Egyptians - leaving only personal statute cases to the Islamic courts.

${ }^{32}$ See generally Leonard Wood, Islamic Legal Revival: Reception of European Law and Transformations in Islamic Legal Thought in Egypt, 1875-1952 (Oxford Univ. Press 2016).

${ }^{33}$ Baldwin, supra note 22, at 41. See also Ron Shaham, Family and the Courts in Modern Egypt: A Study based on Decisions by the Shari a Courts, 1900-1955 (Brill 1997).

${ }^{34}$ It represents the conclusion of a process that has been functioning for nearly a century to bring to an end the six centuries old Shar $i$ (religious) State in Egypt.

${ }^{35}$ Qanun bi-llgha'a'-Mahakim al-Shari'ia wa al-Millya [Law 462 of 1955 on the Abolition of the Shari'a and Milli Courts], at art. 1. Suits that will have remained unresolved ... were to be shifted to the national courts which should deal with them in accordance with their own code of procedure and in accordance with the current law. 
courts. ${ }^{36}$ Also, the law provides for the establishment within the national jurisdiction of first instance and appellate courts to deal, according to the national code of procedure, on issues pertaining to family matters and to waqfs (endowments) that used to be in the exclusive competence of the Shari iand the communal courts. ${ }^{37}$

In the same vein, the law establishes that regarding family disputes and wqfs falling within the competence of the Shar $i$ courts, the domestic courts shall follow the civil code of procedure except where certain rules had been issued for the Sharie'a courts and for other complementary laws. ${ }^{38}$ Also, all Shar $i$ jurisdiction (rulings) shall be issued according to the most approved opinion of the Hanfi school of thought - the most moderate - except where specific law has been issued. ${ }^{39}$ As for disputes of family conflicts of Non-Muslim Egyptians (Coptic Christians and Jews [at that time]) confession and who have organized communal jurisdiction at the time of the enactment of this law, the sentences shall be issued according to their own laws taking into account the public order. ${ }^{40}$ In this context, the law reads "The rules of public order, require that the sovereignty of the state be complete and absolute in the interior, and that all those who live in it, without distinction of nationality, be submitted to the laws of the country, to its courts and to a single juridical jurisdiction, taking into account the diversity of the conflicts ratione materim and of the laws applied to them." But in Egypt the situation contradicts this principle, as the jurisdictions to which the Egyptians themselves submit in matters of family issues are many. ${ }^{41}$

Regarding family law matters, Egypt has inherited from the past a diversity of judicial organizations, and hence, the Shar $i$ courts were recognized, and then, the communal courts;

36 Id., at art. 2. It should be noted that one of the main rules for the appointment of the dayanim (Rabbinical court judges) in Israel is that judges must have wisdom and humility and awe and hatred of money and the love of truth and the love of the people and known for their "Shem Tov" (decency). See Rambam, Sanhedrin 42b (Jewish halakha).

$37 / d$., at art. 3. It also stipulates that "in matters pertaining to personal status, the court of first instance shall be composed of a bench of three judges which may include one or two members of the benches of the equivalent Shar $i$ courts who will have been attached to the civil cadres." The same norms applies to the appellate courts, except that there only one Shar'i judge must be included in the bench.

$38 / d$., at art. 5.

39 Id., at art. 6.

${ }^{40}$ See Wael B. Hallaq, The Origins and Evolution of Islamic Law (Cambridge Univ. Press 2005) (The Egyptian laws, most case law and legal literature refer to Christians and Jews as ghayr almuslimin (nonMuslims). Occasionally, the Islamic terms ahl-al-dhimma (protected people under Islamic sovereignty) and ahl-alkitab (people of the book) are also used in that context. Article 7 of this law reads that "change of confession or communal affiliation of a party to the dispute in the course of the procedure shall not affect its march, unless the change is done in the favor of Islam, in which case the first clause of article six shall be applied" and in the same vein, Article 9 reads "for merging the judges of the Shar'i courts of all levels in the cadres of the national courts, the committees on personal status or the technical committees of the Justice Ministry."

${ }^{41}$ Harald Motzki, The Origins of Islamic Jurisprudence (2001). In this respect, each jurisdiction applies its own law and its own peculiar procedure without any bond uniting them, and without any organism to preside over its judicial activity. This has been the situation even though the nation has already reassumed its judicial privileges about foreigners, so that the national courts have become entirely competent in all their disputes, even in those that relate to their personal status. 
expanded until each community attained a specific jurisdiction, with all the precise legislation and procedure that this infers. ${ }^{42}$ Many conflicts arose between the various jurisdictions, giving rise to contradictory reactions on the same issue, and thus, that having repressed the rights which certain citizens of foreign countries enjoyed, and having submitted their subjects to the regular regime of justice before the domestic courts. ${ }^{43}$ In this regard, the non-Muslim communities have been possessing - at that time - fourteen sevarl jurisdictions, some of which sit only at very long intermissions and in areas remote from the parties' homes. ${ }^{44}$ It should be noted that the judiciary fees are not unified; as some of these courts do not have any clear regulation on this issue and most of these courts do not have a regular judicial corps to fulfil their commitments. ${ }^{45}$ However, from a policy reform perspective, paths to access justice to the general public was complicated, as the government cannot suffer the presence of the national territory of judiciary sovereignties. Thus, shar $i$ judges and lawyers were in charge of the interpretation of the clauses referring to change of confession or collective affiliation. ${ }^{46}$

In the same vein, the Egyptian legislator has already adopted it in Article 13 of the Civil Code which says that "divorce is subject to the legislation of the country to which the husband belongs at the time of the divorce [and] the law that governs the process and the separation is that of the husband at the time of the opening of the process." ${ }^{37}$ Historically speaking, since the Shar i qadis, will in fact sit in the national courts to decide (or judge) family law conflicts for both Muslims and non-Muslims alike, which means that the new law "does not impose on

\footnotetext{
42 Noah Feldman, The Fall and Rise of the Islamic State (2008) (revealing how the classical Islamic constitution governed through and was legitimated by law and shows how executive power was balanced by the scholars who interpreted and administered the shari'a, and how this balance of power was destroyed by the tragically incomplete reforms of the modern era). Feldman argues "that a modern Islamic state could provide political and legal justice to today's Muslims, but only if new institutions emerge that restore this constitutional balance of power."

${ }^{43}$ All these are fragments of Ottoman legislation which applied then to Egypt and these legislative vestiges were not stimulated in their substance and their explanations by a desire for clarity and precision; as they were, the fruit of deliberate unawareness which was forced by the political circumstances at the time.

44 This makes the justice process very difficult for some individuals and shows oppressional indications. ${ }^{45}$ Hallaq, supra note 15. Further, a person shall not be qualified to be appointed as a judge in a regional rabbinical court in Israel unless (a) he was ordained to the Rabbinate "Yoreh Yoreh Yadin Yadin" (qualification's level in the Jewish halakha) by an expert rabbi or Torah institution that the Council of the Chief Rabbinate; (b) he is thirty years old and married [or divorced]; (c) his way of life and character suit Dayan's status in Israel, and (d) passed all the examinations conducted by the Judicial Council unless he is exempted by the Council. See REgulations OF THE DAYANIM (Terms of Certification and its Regulations) 1-1955.

46 It should be emphasized that the application of a recognized principle whereby the changing of religion entails upon the individual about the rights of his/her new religion. This rule is completely like that governs nationality's change.

47 See AL-QANUN AL-MADANI AL-MASRY [The Egyptian Civil Code Law No.131 of 1948 in force since October 15,1949]. The enactment of this law provision was followed by an instantaneous energetic reaction on the part of the Copts minorities in Egypt. Within a few days the spiritual leaders of all the Christian communities in Egypt assembled in the seat of the Coptic-Orthodox patriarchate to advise on an action plan which leads in the end that they unanimously adopted a memorandum which they addressed to President Gamal 'Abd al-Nasser on October 3, 1955.
} 
everybody a single civil legislation which deprives Muslims and non-Muslims equally of the application of their own religious law - on the contrary, the Muslim legislation will in fact be applied to Muslims and even to non-Muslims" in at least two cases; (a) when the parties are not of the same Christian denomination, (b) and when one of the parties adopts Islam even in the course of the consideration of the case. ${ }^{48}$ Accordingly, Christians definitely will not accept that, and urged the President to continue allowing Christians to have their own religious courts, which dates from the days of Prophet Mohammad and the Qur'an. ${ }^{49}$ They argued that will setup a danger precedent for Muslims by establishing a model of enforcing the religious law of the majority on the minority. ${ }^{50}$

Accordingly, the clumsiness of the circumstances in which Muslim qadis would be applying Christian canon law, it cannot fail to attack the observer that when a government cannot tolerate independent judicial organizations on sovereignty grounds, it is not likely to put up for long with independent legislative authorities, which must be the case if the non-Muslim Egyptians are to be tried according to their own law. ${ }^{51}$ Then, the government decided to establish a unified law for all citizens, as this legislation cannot be the Muslim law both for clear political motives and because the government itself is not satisfied with the current family laws, which are the outcome of past negotiations between secular's westernizers and conservatives that left several desirable improvements unrealized. ${ }^{52}$ It should be mentioned that the government established an obvious conflict between "the rules of [public] law" regarding sovereignty and the congenital Egyptian classical 'adaat (traditions and customs) which provided for the launching of autonomous Shar $i$ courts. ${ }^{53}$ For the first time - in the Egyptian

\footnotetext{
48 Religious leaders - at this point - argued that this reflects "trafficking in religion" and insisted that marriage in Christianity is essentially a religious contract governed by eternal or immutable divine law, as Jesus Christ said that "No man has the right to separate that which God has united." History explains that communal jurisdiction is not contradictory to the national sovereignty notion.

${ }^{49}$ See generally Bernard G. Weiss, The Spirit of Islamic Law (1998) (outlines the prominent features of Muslim juristic thought: espousal of divine sovereignty; a fixation on divine texts; an uncompromisingly intentionalist approach to the interpretation of those texts; a frank acknowledgment of the fallibility of human endeavor to capture divine intent; a toleration of legal diversity, and a moralistic bent grounded in a [specific] social vision).

50 See Matthijs de Blois, Religious Law Versus Secular Law: The Example of the Get Refusal in Dutch, English and Israeli Law, 6 UTRECHT L. REV. 2 (2010).

51 The rulings of the Court of Cassation are published in an annual collection known as MajmaatalAhkam li-Mahkamat al-Naqd [Collection of Rulings of the Court of Cassation], published by elMaktab alFannï in Cairo.

52 Religious leaders along with legal authorities have been in favor of civil marriage legislation for both Muslims and non-Muslims. Moreover, the Justice Minister - at that time - decided the enactment of the new law with "necessary complements" to the oppression of the autonomous jurisdictions.

${ }^{53} \mathrm{~A}$ notable illustration of trying to complicate the issues is the attempt made to validate judging a convert to Islam according to Islamic law even if the conversion takes place during the consideration of the case before the courts. Thus, the law begs the question when it equates the nationality's change with change of religion. Also, it equates two separate acts, as marriage and divorce with a single act at different phases before the courts but the law ignores the inquiry of the noticeable discrimination against Christians, as why is the same principle not applied to change of denomination within Christianity, or from Christianity to Judaism and vice-versa?
} 
modern history - the government faced directly the alternatives between the Sharie'a state courts and one based on western concepts of sovereignty, and chose the latter clearly. ${ }^{54}$ In this regard, a secular legislation had introduced in the last sphere that had remained for divine law, and it should bear in mind that the six-century old Shar i State courts in Egypt has come to an end.

\section{B. The Legal Framework: Interreligious Law, Islamic Law and the Conflict of}

\section{$\operatorname{Law}(s)$}

A religious legal system as Islamic law is both exclusive, because it will not identify other laws let alone apply them, and self-protective (defensive), because it wants to reserve the religious integrity of its community. ${ }^{55}$ Accordingly, some contemporary scholars argue that Islamic law per se (by its nature) does not recognize a concept like conflict of laws, since it will always apply its own law and hence does not allow the problem of conflicting laws to arise. ${ }^{56}$ Although theoretically correct, it should be noted that in order for conflicts law to be operative, some measure of recognition of other legal systems is required. In this domain, there is a major difference between Christianity and Islam: Islamic law recognizes other monotheistic religions and has institutionalized - a level of coexistence - and freedom of religious practice never attained in Christian canonical law. ${ }^{57}$ Nevertheless, although Islamic law accords certain legal liberties to non-Muslim communities, these freedoms may only be exercised within these communities. As soon a Muslim becomes involved in a dispute with a non-Muslim, thus generating a conflict of laws, Islamic law applies. It may consequently be argued that conflicts law does indeed exist in Islamic interreligious law, albeit merely to demarcate the boundaries between the legal spheres of the religious laws. ${ }^{58}$ This separation usually takes place when the limitations are crossed, as in mixed religious marriages and conversion.

\section{What is the dhimmi?}

The legal status of non-Muslims in Muslim countries may differ from their actual social,

\footnotetext{
${ }^{54}$ From the political and legal perspectives, the national courts may still apply a divine - religious - law, if they do, because this law will then be implemented only via tolerance and sanction of the sovereign will, in courthouses formed by the sovereign, acting within a procedure which he/she willfully controls and not by virtue of its being the eternal God law, which is absolute and eternal, binding upon the sovereign and his subjects and applicable generally.

55 See Klaus Wahler, Interreligiöses Kollisionsrecht im Bereich privatrechtlicher Rechtsbeziehungen [Interreligious Conflict of Laws in the Field of Private Legal Relationships] (Cologne: Carl Heymanns Verlag, 1978), 157-158.

$56 / d$.

57 Id., at $159-160$

$58 / d$.
} 
economic and political status. The Islamic perspective regarding the non-Muslims under Islamic sovereignty is compressed in the expression "tolerance of religious pluralism based on inequality." 59 Non-Muslim jurists tend to stress the inequality of non- Muslim residents as second class citizens, whereas most Muslim scholars emphasize the tolerance of Islam. ${ }^{60}$ However, both inequality and tolerance were - and remain -legal realisms which have been colored in various shades of white and black throughout Islamic history. Thus, Islamic law recognizes two categories of legal subjects: Muslims and non-Muslims. Non-Muslims are subdivided into three legal subcategories: $h a r b(s)$ are those who reside outside the Islamic territories, dhimms are those who reside within the Islamic lands, and musta'minin are harbis who are permitted temporary entry into the Islamic territories. In modern terms, international conflicts law would apply to musta'mins, and interreligious conflicts law to dhimms? Islamic law holds that non-Muslim communities living under Islamic rule (dhimms) are entitled to legislative and judicial autonomy about their religious and family (personal status) affairs. This rule is captured by the legal maxim: natruka-hum wa ma yadinüna (We leave them and what they believe). ${ }^{61}$ For all other matters, dhimms were subjected to Islamic law, albeit with modifications to some rules. Modern Arab nation states have adapted the legal status of dhimmlsm order to meet the values of statehood in the nineteenth and twentieth century. The notion of an Islamic imperium run by and for Muslims, with a separate statute for its non-Muslim inhabitants, gave way to the notion of the nation-state, based on the equality of its citizens irrespective of their religious creed. ${ }^{62}$

In the contemporary Egyptian legal system, it grants Egyptian non-Muslims a certain degree of autonomy in family law (personal status) matters, it does so by way of exception. In the first instance, the personal status law of all Egyptians, irrespective of their religion, is governed by Islamic law. This is stipulated in Article 280 of the Decree on the Organization of the Sharie' a Courts before its abolition:

Judgments [in personal status cases] will be passed in accordance with what is stipulated in this Decree, and in accordance with the prevalent opinion of the Abü Hanïfa School of thought $[\ldots]^{63}$

The exception to the overriding jurisdiction of Islamic law is stipulated in Article 6[2] of Law 462 of 1955 on the Abolition of the Shar iaa and Millia Courts, which allows non-Muslims

\footnotetext{
59 DeBlois, supra note 50.

60 ld.

61 Hallaq, supra note 15.

62 In the Hatti Humayoun of 1856, the Ottoman Sultan (leader) abolished the status of dhimmi and proclaimed the equal treatment of all citizens of the empire. One of the few religion-based differences that were maintained was the judicial and legislative autonomy of most religious communities. When Egypt became a British protectorate and therewith gained de facto independence from the Ottoman Empire in 1914, it declared the continuation of the Hatti Humayoun by Law 8 of 1915.

63 Wahler, supra note 55.
} 
to be governed by their own personal family laws, albeit under certain conditions: (a) regarding alhwal shakhsiyya (personal status) of non-Muslim Egyptian [couples] al-muttahid al-ta'ifa wa al-milla (who share the same sect and rite), and who at the time of promulgation of this law have [their own] organized sectarian judicial institutions, judgments will be passed in accordance within sharaie'hom (their own law), all within the limits of al-nizam al amm (public policy). ${ }^{64}$ Egypt's interreligious conflicts law is based on these two articles. According to Egyptian legal doctrine, Islamic personal status law - based on the Hanafi jurisprudence - is the al-qanün al' amm or al-Sharie'a al'amma (general law) in matters of personal status for all Egyptians. ${ }^{65}$

\section{Religious Conversion and the Applicable Law}

Conversion is a situation in which interreligious conflicts law applies. Whereas the conflicts rule regarding the mixed religious marriages is regulated by Law 462 , the conflicts rule about conversion receives only limited attention in Law 462 and is chiefly determined by case Islamic law. In Egypt's interreligious law, it is the religion of the legal subject that regulates which family law is applicable to him/her. Therefore, conversion is not a private religious matter, but an issue with far-reaching legal implications. ${ }^{66} \mathrm{~A}$ Christian may convert to the sect of his/her spouse to avoid application of Islamic law to their marriage. Practically speaking, however, in light of the near impossibility of obtaining a divorce under the Egyptian Christian laws, is the conversion by a Christian to a different sect or rite than his/her spouse to have Sharie'a law, which is much more favorable towards divorce, applied or if Christian wife may have her marriage nullified by converting to Islam. The Court of Cassation has issued two rules of thumb: (1) the decision as to whether a conversion has taken place is to be made by the religion, rite or sect to which one converts, and not the one that is being abandoned. (This rule doesn't apply when a Muslim convert to another religion, in which case, Islam, as the religion that has been abandoned, remains the religion which determines the [invalidity of the conversion); (2) a court may seek to identify whether the convert has complied with the procedures and the conversion rules, but it may not inspect the convert's intentions. Whereas conversion to Islam is easy to establish since it is a unilateral act performed by the mere free will of the convert,

\footnotetext{
$64 / d$.

65 Id. Only when a non-Muslim Egyptian couple fulfills the conditions stipulated in Article 6 of Law 462, will their al-qanün al-khass or al-Sharie'a al-khassa own 'special' non-Muslim law be applied to their personal status affairs, by way of exception to the general law. The criterion by which interreligious conflicts law in Egypt determines which one of the personal status laws applies is therefore religion, as the Supreme court (Cassation Court) has emphasized.

66 Indeed, one can imagine conversion occurring not only for reasons of personal belief, but also as a legal stratagem. In order to establish which law is applicable, the court must determine whether an alleged conversion has taken place. This rule is self-evident in the legal literature, as some justified that a Muslim may never subject to non-Islamic law.
} 
conversion to a Christian rite or sect requires additional recognition by the religious authorities of the rite or sect to which one converts. In both cases, the Court of Cassation has issued numerous rulings. In order to prevent possible abuse of conversion, Article 7 of Law 462 reads that conversion from one non-Muslim rite or sect to another is legally effective only when carried out before the litigation has been originated. During the litigation, the parties will be judged according to the religious law to which they belonged now when they initiated the court case. If, on the other hand, the litigating party converts to Islam, Article 7 requires the immediate applicability of Islamic law, even if the conversion takes place during the litigation.

\section{Sharie‘a Courts or Islamic Judicial Bodies in the West: Are They}

\section{Evil?}

The Sharie' a pattern of justice has been long known to Western Europe with alterations, it functioned for some centuries in Middle Ages. ${ }^{67}$ Historically, Sharie'a laws were in force, as some European countries were occupied by the Ottoman Empire, the influence of which expanded to their judicial and legal systems including the Islamic courts. In the modern Western - European and US - countries, Sharie'a justice that has attracted recent attention, as the issue has been about the formation and functioning of Sharie'a courts, which has been the direct result of the intensive growth of the population of Muslim minorities, who play an increasingly significant role in the social, political and legal life of those countries. ${ }^{68}$ In fact, these processes involve sevral differences which are based on the substantial values and norms between the Islamic and European legal philosophies and the operative experience of these mechanisms strengthens this struggle. ${ }^{69}$

In this domain, it should be mentioned that the the two basic forms of Sharie'a courts to exist. The first is represented by dispute resolution bodies which are founded on the legislation of the country and the second is the presence of religious and public institutions (Sharie'a courts) which are not included in the standard system of legal dispute resolution. ${ }^{70}$

\footnotetext{
67 This refers to Spain, where certain areas were exposed to Muslim conquest and the substantial impact of Islamic laws and Muslim traditions and culture. See, e.g., Michael Kirkland, Under the U.S. Supreme Court: Islamic Law in U.S. Courts, UPI, May 19, 2013, https://www.upi.com/Under-the-US-SupremeCourt-Islamic-law-in-US-courts/64481368948600/ ("Does Islamic law, Sharia, have a place in American courts? A lot of state legislatures don't think so, and there is a movement to ban its application in domestic courts, state and federal ... Sharia, based on the sayings of the Prophet Muhammad, is often a consideration in family issue cases involving U.S. Muslims. But its precepts apply to all aspects of life, and its severest critics allege it is a factor in some acts of terror . . . During those two years, Arizona, Kansas, Louisiana, Oklahoma, South Dakota and Tennessee enacted such bills. In Oklahoma, the law explicitly banned judicial consideration of Islamic law, or Sharia. The ban was approved by the voters.") 68 See generally Leonid R. Sykiainen, Islamic Law: Interaction between Legal and Religious Sides, ANNUAL OF LIBERTARIAN LEGAL THEORY 1 (2007).

69 Hallaq, supra note 15 .

70 ld.
} 
Moreover, there are bodies which combine the tasks of courts and religious organizations at the same time.${ }^{71} \mathrm{~A}$ significant example of a European country where the Sharie' a justice model is applied not only in the form of divine or public institutions but also as bodies of judicial or alternative dispute resolution within the framework of the law is the United Kingdom. ${ }^{72}$ In most cases, these judicial bodies resolve family and minor property disputes and most of the decisions taken by those courts refer to dissolution of marriages, divorces and their consequences and their decisions - as these issues could be against the UK law program represents the negative trend of the public opinion in the UK. ${ }^{73}$ British religious leaders and scholars promoted the official notion of acknowledging Muslim's right to follow their law(s), and of including some of these rules in the country's legal system and they argued that there is no reason for UK national courts not to admit decisions based on the Sharie'a values. ${ }^{74}$

The main harsh criticism from the media and some far-right wings - all over the globe - that the key arguments came down to the fact that Islamic norms were applied for the sake of reasoning the discrimination against women and actual polygamy, prohibition for Muslim women to marry non-Muslim men, legalization of forced marriages, the restriction of women's rights after divorce, and the severe criminal punishments. ${ }^{75}$ One of their main arguments to deny Sharie'a courts that they do not meet the modern human rights and justice standards; however it is equally unfair to disapprove the Islamic justice model as a whole based on the activity of certain institutions. ${ }^{76}$ In the same vein, there are other Sharie'a courts which work legally correctly and truly function within the legal framework of the UK legislation, as for instance those were formed and function in accordance with the Arbitration Act of 1996. ${ }^{77}$ This law allows an arbitration tribunal by agreement of the parties - at their own motivation - apply to it for the resolution of their [civil] conflict, and who are willingly ready to follow the decision made by this body - taking into account - that cases regarding public interest or disputes requiring serious consideration cannot be resolved by arbitration proceedings, as criminal

\footnotetext{
$71 / d$.

72 In 1980s, the appearance of these judicial bodies started in the UK, as the first one was the Islamic Sharie'a council created in 1982 in Leyton and some of these bodies are sometimes charitable and their decisions have no legal standing.

73 See Women's Equality in the UK: A Health Check, Women's Resource Centre (Apr. 2013), https://tbinternet.ohchr.org/Treaties/CEDAW/Shared\%20Documents/GBR/INT CEDAW NGO GBR 1 3333 E.pdf. Shadow report from the UK CEDAW Working Group assessing the United Kingdom Government's progress in implementing the United Nations Convention on the Elimination of All Forms of Discrimination Against Women (CEDAW). See also UN GENERAL ASSEMBLY, Convention on the Elimination of All Forms of Discrimination Against Women, Dec. 18, 1979, United Nations, Treaty Series, Vol. 1249, at 13, http://www.refworld.org/docid/3ae6b3970.html (last visited Feb. 29, 2020)

74 John R. Bowen, How Could English Courts Recognize Shariah? 7 ST. ThOMAs L. J. 3 (2010).

$75 \mathrm{Id}$. Radical opponents and activists of these courts stated that Muslim women apply to these bodies not of their own will but compulsorily since Muslim communities essentially prohibit them from looking for the protection of their rights by applying to state courts, which is totally inaccurate.

76 Weiss, supra note 49.

77 See, e.g., UK ARBITRATION ACT OF 1996, at https://www.legislation.gov.uk/ukpga/1996/23/contents.
} 
cases. $^{78}$

It should be noted that the Muslim arbitration tribunal is one of the most authoritative bodies among them, as it takes up cases of forced marriages and domestic violence, family disputes, divorce, commercial and debt conflicts, inheritance cases and fights in mosques. ${ }^{79}$ The decisions the tribunal makes - takes into consideration - the British law as well as the conclusions elaborated by the acknowledged jurisprudential school of Islamic law. ${ }^{80}$ In Canada, a similar neutral view of the Sharie' a courts had a conclusive impact on the functioning of religious arbitration. ${ }^{81}$ The Canadian act allows for the arbitration of family cases and the arbitration contract on these matters is considered to be a private contract stipulated in the 1990 Act on family law and is to be executed in compliance with it. ${ }^{82}$

In 2003, the Congress of Canadian Muslims decided to establish a similar structural body for Muslims and the Islamic Institute of Justice was created, which used Sharie'a arbitration within its framework implementing the 1991 Arbitration Act. ${ }^{83}$ Thus, the prohibition of free choice is restricted to family issues only and western communities argued that no danger in implementing Sharie'a norms for issues other than family ones and this trend has something in common with the estimation of the Sharie'a justice in European countries, such as Germany, Spain, Belgium, and the UK where there are unofficial Sharie'a courts within Muslim communities. ${ }^{84}$ Sharie'a courts can be established and function in compliance with the federal legislation (the law of the land) - taken into account - that its formation by some Muslim bodies is not sufficient enough to characterize it as an Islamic court, as the main feature of a Sharie' a court is that it implements the moderate fixable Islamic (sharie'a) norms. ${ }^{85}$ This notion

\footnotetext{
$78 / d$. The parties before the arbitration tribunal have opportunities to set the procedural regulations to resolve the dispute and they are entitled to choose the legislation applied to their dispute. 79 ld.

${ }^{80}$ ARBitration Act, at Procedural Rules, supra note 65.

81 See, e.g., Arbitration Act, 1991, S.O. 1991, c. 17 (Ontario, Canada), at https://www.ontario.ca/laws/statute/91a17.

82 Nevertheless, the arbitration acts coincided until 2006 in that the parties of the arbitration case themselves determined the legislation to be used in resolving the conflict. By the beginning of the 2000s, arbitration bodies of confessional and national orientation had been formed, especially, there were courts for Jews, followers of various branches of Christianity and for the aborigines. See, e.g., ARBITRATION ACT 1996, at http://www.legislation.gov.uk/ukpga/1996/23/data.pdf. (last retrieved Feb. 29, 2020).

83 See, e.g., Family Statute LaW Amendment Act 2006, S.O. 2006 c.1, at http://www.ontario.ca/laws/statute/s06001/ (last visited Feb. 29, 2020).

84 Trevor C.W. Farrow, Re-Framing the Sharia Arbitration Debate, 15 ConstITUTIONAL FoRUM 2 (2006).

85 Reconciliation procedures are explained in detail in the Islamic concept of dispute resolution and Islamic transitional justice. For further account on the Islamic reconciliation, see, e.g., Mohamed 'Arafa, Transitional Justice, the Seeds of Change: Secular Law or Divine (Islamic) Law, Quo Vadis? 9 CREIGHTON INT'L \& COMP. L. J. 2 (2018), https://dspace2.creighton.edu/xmlui/handle/10504/117686. Thus, the Islamic norms can be applied to gain the case' agreement and its confirmation by the arbitral court. Arbitration courts can work in accordance with their personal rules or the rules agreed upon by the parties and such procedures can be orientated to the Sharie'a conditions that compatible with the practice adopted in the positive law norms.
} 
is confirmed by the view of the modern Islamic jurisprudential thought on civil courts and the prospect of using these institutions for dispute resolution within the Sharie'a.

\section{Public Policy Concerns: What is Islamic Public Policy in Sharie'a}

\section{Courts?}

Public policy cases mostly demonstrate that public policy in Egyptian interreligious laws has a variety of tasks. The Egyptian legal system and the Supreme Court (Court of Cassation) do distinct between 'negative' and 'positive' public policy. Defensive (negative) public policy prevents unsolicited rules of foreign law from being applied, after conflicts law(s) has recognized that they are applicable. ${ }^{86}$ On the other hand, assertive (positive) public policy relates to the rules of national law that are considered of indispensable importance for the national legal order, as it prevents parties from deviating from these laws. ${ }^{87}$ Thus, positive public policy in Egyptian interreligious law applies to both codified and uncodified rules, as the tasks of positive and negative public policy serve the interests of the crucial values of Islamic law, which it may happen that the important interests of non-Muslim legislations are violated by the Islamic law's application. ${ }^{88}$ Does this constitute a breach of the Egyptian public policy? According to the Court of Cassation, "Egypt's public policy does not exemplify vital principles of non-Muslim laws, though, a crucial rule of Islamic law, including public policy, is the protection of the dhimmi (non-Muslim) principles and rights." 89 Thus, various legal scholars argued to qualify the reverse effect of the dhimmi feature of public policy as Islamic public policy. For instance, when non-Muslims are exempted from Islamic rules as they do not need to have two male witnesses to a marriage, these norms remain significant to Islamic law and

\footnotetext{
${ }^{86}$ For more details on the interaction between Islamic law and civil law in the context of the last 150 years of Egyptian real property law, see RICHARD A. DEBS, ISLAMIC LAW AND CIVIL CODE: THE LAW OF PROPERTY IN EGYPT (2010). See, e.g., Article 6 of Law 462 of 1955, supra note 3. Even the interreligious conflict of laws determines that a non-Muslim legislation is applicable, those rules which are considered a violation of public policy will not be implemented.

${ }^{87}$ Id. For example - in the field of the criminal law - positive public policy can be a law of public policy in its entirety, as it can never be set aside by foreign rules, nor can citizens agree to deviate from it.

88 TARIQ AL-BISHRI, AL-WAD 'AL-QANUNI AL-MU'ASIR BAYN AL-SHARIE'A WAAL-QANUN AL-WAD'I [The Position of Modern Law: Between the Islamic Shari a and Positive Law] 5-6 (1996) (criticizing nineteenth-and twentieth-century reforms for creating parallel institutions rather than integrated ones). It should be mentioned that in Israel, for example, there are some critics regarding the judges of the religious courts as they lack legal education; to know the secular Jewish society; political ideals, as most of the Dayanim are ultra-Orthodox and the ultra-Orthodox parties stand behind them. It is much more blatant in the religious courts system, as the judicial appointment process in the civilian courts system determined by various parties - Haredi parties - and only men - it is not written anywhere, but clear as the first condition is the recognition by the Chief Rabbinate of Israel, as women are not accredited till now.

${ }^{89}$ For more account on al-Sanhūrī and his contributions to modern Islamic law, see Enid Hill, The Place and Significance of Islamic Law in the Life and Work of 'Abd al-Razzāq al-Sanhūrī, Egyptian Jurist and Scholar, Part I, 3(1) ARAB L. Q. 33 (1988) and Part II, 3(2) ARAB L. Q. 182 (1988). Accordingly, the breach of these policies by Islamic law might be considered unjust.
} 
consequently part of public policy, though for Muslims only. ${ }^{90}$

So, the question is how to determine what public policy is? Positive law and man-made rules attain the status of public policy by a court's ruling, in which the essence of public policy is considered to be part of the national legal order may change with time, and the competence to evaluate the essential mechanisms of the legal order at any given time is bestowed in the courts. ${ }^{91}$ It should be noted that it is - still - perplexing that specific rules of Egyptian legislation obviously have a public policy nature, but are not cited as such by case law or in the legal doctrine, especially the American common law system. ${ }^{92}$

To obtain an inclusive view of Egyptian positive public policy in the case law, two distinctive features should be realized. First, there is a distinction between Muslims and nonMuslims in which these two communities are to be treated differently. Most rules are sort of discriminatory, based on the Islamic maxim, "Islam supersedes and cannot be superseded" means that a non-Muslim should not have wilaya (legal authority) over a Muslim, and that a Muslim can never be subjected to non-Muslim law. Second, except for inheritance issues, the feature of public policy is typically considered to be self-evident; in which legal foundations, reasoning (justifications) are rarely presented, so, all matters of family law - explicitly or implicitly - to be of public order, are uncodified. ${ }^{93}$ As long as Egypt maintains its system of interreligious law, public policy will serve to preserve the balance between Muslim and nonMuslim family law. ${ }^{94}$ It is should be emphasized that the main task of both positive and negative public policy is to guarantee the essential principles of Islamic law, along with the protection of the essential values of non-Muslim laws, which always occurs in cases in which non-Muslims of different rites and sects are governed by Islamic law. ${ }^{95}$ In this regard, the Court of Cassation

\footnotetext{
90 These rules constitute Islamic public policy (Egypt's public policy which in most circumstances applies only to the Muslim Egyptians).

91 See Baber Johansen, The Relationship Between the Constitution, the Shari'a and the Fiqh: The Jurisprudence of Egypt's Supreme Constitutional Court, 64(4) ZEITSCHRIFT FÜR AUSLÄNDISCHES ÖFFENTLICHES RECHT UND VÖLKERRECHT 881, 882 (2004). ("In the twentieth century, the fiqh norms that are introduced into the modern codes of the Arab states owe their validity to the fact that the national legislators has enacted them. In other words, these norms no longer qualify as a jurists' law."). 92 See Asifa Quraishi-Landes, Five Myths about Sharia, THE WASHINGTON POST, June 24, 2016, https://www.washingtonpost.com/opinions/five-myths-about-sharia/2016/06/24/7e3efb7a-31ef-11e68758-d58e76e11b12 story.html (last visited Feb. 29, 2020).

${ }^{93}$ Baudouin Dupret, What is Islamic Law? A Praxiological Answer and an Egyptian Case Study, 24 THEORY, CULTURE \& SOC'Y (2), at 79-88 (2007) (describing the practice of an Egyptian judge, even when implementing "Islamic" norms, as one that seeks: "[T]o publicly manifest the correct accomplishment of his job. At this procedural level, it is obvious that the judge orients himself exclusively to the technicalities of Egyptian procedural law. These technicalities may include some reference to provisions explicitly relating to Hanafite or Malikite law, but this is always through the provisions of Egyptian law, as interpreted by the Court of Cassation.").

94 Moderate Muslim scholars argues that interreligious law in Egypt has always been "balanced, preserving the harmony which it had for fourteen centuries, until its disruption by Law 462 of 1955 ." In other words, in the Egyptian legal system, public policy is derived from one legal order (Islamic law) but its role is not essentially to endorse the norms of this order but to preserve an equilibrium between the Muslim and non-Muslim legal orders.

${ }^{95}$ See, e.g., Law No. 25/1920 on Maintenance and Personal Status, Law No. 25/1929 of Personal Status
} 
has ruled that "the Islamic rules of polygamy, divorce (only for Catholics), and the requirement of witnesses for the conclusion of a marriage constitute a violation of essential principles of the Christian faith." ${ }^{\prime 96}$

\section{Conclusion: The Face, the Back, and the Future of the Sharie'a}

\section{Courts}

In Egypt's system of interreligious law, the various religious personal status laws, is de facto treated as a duality (Muslim and non-Muslim laws). Regarding the interreligious law conflict's issue, it should be noted that, however, the predominant norms and rules are Islamic - in nature - to decide which law is applicable when more than one religious law applies to an individual or specific situation (as religious conversion or mixed marriages), Islamic law - in most cases - will prevail. Public policy can be applied when it can endorse Islamic norms (positive public policy), as it can prevent non-Muslim rules from being applied as they breach the essential Islamic law norms which constitutes (negative public policy) and may protect critical standards of dhimmi public policy (non-Muslim laws). In the first half of the twentieth century, the legislative policy focused mostly on the twahid (unification) of personal status laws, interreligious law in the second half of the century has been dominated by case law, in which public policy played a fundamental role. ${ }^{97}$

It is via public policy that the restrictions between the realms of Muslim and non-Muslim legislations have been further defined and accustomed. Although - since 1970s - public policy is typically defined as a secular notion, courts and legal doctrine have progressively interpreted it as an Islamic concept. This means that the independent position of non-Muslim family laws will not be subjected to unification, because interreligious law is a rudimentary rule in Islamic law and public policy in its Islamic shape may place further boundaries on this autonomy. The conclusion is that some western countries has all the legal grounding to apply Sharie'a justice techniques in the form of dispute adjudication via mediation. Though, this attitude can be disputed regarding the practice of unofficial Sharie'a courts in the West. Mediation agreements being the result of application of the mediation process may mean the implementation of

\footnotetext{
(marriage's dissolution \& family disputes), Civil Code No. 38 of 1931, Law No. 77/1943 \& No.71/1946 on Inheritance \& Bequest.

${ }^{96}$ See Nos.16 and 26, Year 48, Jan. 17, 1979; No.1392, Year 50, Feb. 5, 1984; No.31, Year 53, Apr. 10, 1984. As a public policy matter, the Court cited that: "these Islamic rules should not be applied to mixed Christian marriages, not because these rules constitute a violation of public policy, but because the protection of essential non-Muslim principles is considered a rule of public policy [...] This function is intrinsically connected to what several scholars call Islamic public policy, that part of Egyptian public policy which applies only to the Muslim community."

${ }_{97}$ See generally Sumner B. Twiss, Marian Gh. Simion, Rodney L. Petersen, Religion and Public Policy: Human Rights, Conflict, and Ethics (Cambridge Univ. Press, 2015).
} 
Sharie'a norms violating this practice's influencing. These recent progresses show how Egyptian law properly adheres to the legacy of Islamic law that permits for new albeit bland interpretations of Islamic law that are of a secular than religious nature.

The legal possibility for Sharie'a justice in the West in the form of arbitration courts doesn't testify to the need for them, however, the reasons of the formation of such institutes are significant. First and foremost, forms of Sharie'a justice which are stipulated in Western law and operate within its framework should be set against the unofficial Sharie'a courts carrying out illegitimate action. It is of great importance to keen on the fact that these prohibited structures often refer to ancient customs against which Sharie'a wins since many of its norms and concepts meet the criteria of the law. That is why the formation and activity of the Islamic justice model in forms recognized by the legislation can contribute to overwhelming classical traditions and become a step towards the affirmation of values of justice in Muslim's life. While formally preserving adherence to Islamic law, Egyptian interreligious law has effectively been secularized, in the sense that typical Islamic norms have been abandoned in favor of principles that are not necessarily 'Islamic'. With no doubt, the experience of Sharie'a courts and Islamic tribunals, on any forms of Sharie' a justice is still argued hardly and debated actively. ${ }^{98}$ Sharie'a (Islamic law's) application - in some Muslim countries - needs a deep reform in the first place. The Islamic world needs a cultural revolution, enlightenment, critical thinking and humanism and they should ditch once and for all religious law.

Recebido em 09/03/2020

Aprovado em 20/04/2020

Received in 09/03/2020

Approved in 20/04/2020

\footnotetext{
98 See Shariah in American Courts: The Expanding Incursion of Islamic Law in the U.S. Legal System, CENTER FOR SECURITY POLICY PRESS, Jan. 5, 2015, https://www.centerforsecuritypolicy.org/2015/01/05/shariah-in-american-courts-the-expandingincursion-of-islamic-law-in-the-u-s-legal-system/ (last visited Feb. 29, 2020) ("Most Americans take the rule of law and our constitutional rights for granted. Yet, Shariah in American Courts is a reminder of how even institutions like our judiciary can be influenced - and potentially subverted - by foreign legal codes and practices, to the grave detriment of our nation and liberties.").
} 